
VOLUME 10 NOMOR 6 DESEMBER 2021

ISSN : 2303-1514 | E-ISSN : 2598-5949

\title{
UPAYA MENINGKATKAN KEMAMPUAN BERFIKIR KRITIS IPS SISWA MELALUI PEMBELAJARAN DISCOVERY LEARNING DI SDN 111 PEKANBARU
}

\author{
Elpri Darta Putra ${ }^{1}$, Siti Quratul Ain ${ }^{2}$, Eva Astuti Mulyani ${ }^{3}$, Mitha Dwi Anggriani ${ }^{4}$ \\ ${ }^{1,2,4}$ Universitas Islam Riau, Pekanbaru, Indonesia \\ ${ }^{3}$ Universitas Riau, Pekanbaru, Indonesia \\ 1elpri.dp@edu.uir.ac.id, ${ }^{2}$ quratulain@edu.uir.ac.id, ${ }^{3}$ eva.astuti@lecturer.unri.ac.id,
}

\section{EFFORTS TO IMPROVE STUDENTS' SOCIAL SCIENCE CRITICAL THINKING SKILLS THROUGH DISCOVERY LEARNING AT SDN 111 PEKANBARU}

\begin{tabular}{|c|c|}
\hline ARTICLE HISTORY & ABSTRACT \\
\hline $\begin{array}{l}\text { Submitted: } \\
08 \text { Oktober } 2021 \\
08^{\text {th }} \text { October } 2021\end{array}$ & $\begin{array}{l}\text { Abstract: This study aimed to determine the teacher's efforts in improving students' social } \\
\text { studies critical thinking skills through the discovery model at SDN } 111 \text { Pekanbaru. The } \\
\text { research design used was CAR (Classroom Action Research). This research was conducted on } \\
\text { fifth-grade students of SD Negeri } 111 \text { Pekanbaru in the odd semester of the } 2020 / 2021 \\
\text { Academic Year, with } 27 \text { students. This classroom action research was conducted through four } \\
\text { stages: planning, implementation, observation, and reflection. This research consisted of } 2 \\
\text { cycles. Each cycle consisted of planning, implementation, observation, and reflection to } \\
\text { continue the next cycle.Meanwhile, the data analysis technique in this study was descriptive } \\
\text { statistical analysis to describe data about the teachers' and students' activities to be observed. } \\
\text { The results were that the Discovery Learning model improved students' critical thinking, which } \\
\text { was seen from students' learning outcomes in social studies subjects at grade V of SDN } 111 \\
\text { Pekanbaru. Obviously, the social studies learning process before the implementation of the } \\
\text { Discovery Learning model had a low percentage level, namely } 3.70 \% \text {. Meanwhile, after } \\
\text { implementing the Discovery Learning model, there was a significant increase. In the first cycle, } \\
\text { the results were } 37.04 \% \text {, while in the second cycle, the learning outcomes were } 92.59 \% \text {, with } \\
\text { the number of students who completed as many as } 25 \text { students from } 27 \text { students at grade V of } \\
\text { SDN } 111 \text { Pekanbaru. }\end{array}$ \\
\hline
\end{tabular}

Accepted:

28 November 2021

$28^{\text {th }}$ November 2021

Published:

27 Desember 2021

$27^{\text {th }}$ December 2021
Keywords: social studies, discovery learning model, PTK

\begin{abstract}
Abstrak: Penelitian ini bertujuan untuk mengetahui upaya guru dalam meningkatkan kemampuan berfikir kritis IPS melalui model discovery siswa di SDN 111 Pekanbaru. Desain penelitian yang digunakan adalah PTK (Penelitian Tindakan Kelas). Penelitian ini dilaksanakan pada siswa kelas V SD Negeri 111 Pekanbaru, pada semester ganjil Tahun Ajaran 2020/2021, dengan jumlah siswa 27 orang. Penelitian tindakan kelas ini dilakukan melalui empat tahap yaitu: perencanaan, pelaksanaan, pengamatan dan refleksi. Penelitian ini terdiri dari 2 siklus yaitu siklus pertama dan siklus kedua. Setiap satu siklus terdiri dari perencanaan tindakan, pelaksanaan tindakan, pengamatan/observasi dan refleksi untuk dilanjutkan ke siklus berikutnya. Sedangkan teknik analisis data dalam penelitian ini adalah analisis statistik deskriptif dengan tujuan untuk mendeskripsikan data-data tentang aktifitas guru dan siswa yang akan diamati. Hasil penelitian yang didapatkan adalah bahwa dengan menggunakan model Discovery Learning dapat meningkatkan berpikir kritis siswa dilihat dari hasil belajar siswa pada mata pelajaran IPS di kelas V SDN 111 Pekanbaru, terlihat jelas bahwa proses pembelajaran IPS sebelum dilaksanakannya model Discovery Learning yaitu memiliki tingkat persentase yang rendah yaitu $3.70 \%$ Sementara itu, sesudah diterapkannya model Discovery Learning di kelas V SDN 111 Pekanbaru ini mengalami peningkatan yang cukup signifikan. Pada siklus I, hasil sebanyak 37.04\% sedangkan pada siklus II, hasil belajar $92.59 \%$ dengan jumlah siswa yang tuntas sebanyak 25 siswa dari 27 siswa di kelas V SDN 111 Pekanbaru.
\end{abstract}

Kata Kunci: IPS, model discovery learning, PTK 


\section{CITATION}

Putra, E, D., Ain, S, Q., Mulyani, E, A., \& Anggriani, M, D. (2021). Upaya Meningkatkan Kemampuan Berfikir Kritis IPS Siswa Melalui Pembelajaran Discovery Learning Di SDN 111 Pekanbaru. Primary: Jurnal Pendidikan Guru Sekolah Dasar, 10 (6), $1704-$ 1717. DOI: http://dx.doi.org/10.33578/jpfkip.v10i6.8616.

\section{PENDAHULUAN}

Sebuah bangsa yang besar adalah jika elemen masyarakatnya berpendidikan dan mampu memajukan negaranya. Pendidikan sebagai kunci semua kemajuan dan perkembangan yang berkualitas, sebab dengan pendidikan manusia dapat mewujudkan semua potensi dirinya baik sebagai diri sendiri maupun sebagai masyarakat. Hal ini karena, tujuan utama yang ingin dicapai oleh pendidikan adalah optimalisasi dan aktualisasi potensi manusia. Menurut Hamalik (2010) pendidikan merupakan suatu proses dalam rangka mempengaruhi seseorang supaya mampu menyesuaikan diri sebaik mungkin dengan lingkungannya, dan akan menimbulkan perubahan dalam individual yang memungkinkan untuk berfungsi dalam kehidupan masyarakat.

Pendidikan pada hakikatnya dapat mengembangkan aspek pembelajaran yang diberikan sejak masih kecil hingga tumbuh menjadi anak-anak, remaja, dan dewasa. Setiap anak akan berkembang sesuai dengan pengalaman yang diberikan kepadanya melalui sebuah proses yang dinamakan belajar. Pada umumnya, anak akan mengalami belajar baik berada di lingkungan sekolah maupun lingkungan luar sekolah. Menurut Ghufron (dalam Alsa, 2014) berpendapat bahwa belajar adalah tahapan perubahan perilaku individu yang relatif menetap sebagai hasil pengalaman dan interaksi individu dengan lingkungan.

Keberhasilan siswa dalam belajar dituntut untuk giat agar mencapai hasil belajar yang baik dan maksimal. Keberhasilan belajar siswa ditandai adanya perubahan-perubahan pada diri siwa untuk sendiri, perubahan itu antara lain perubahan pola pikir, pemahaman, perasaan, dan tingkah laku secara umum.
Keberhasilan belajar siswa dipengaruhi oleh beberapa faktor, antara lain : pertama, faktor internal (faktor dari dalam) yaitu faktor dari keadaan/kondisi jasmani dan rohaninya siswa. Kedua, faktor eksternal (faktor dari luar) dimana faktor ini menjelaskan tentang kondisi lingkungan di sekitar siswa. Ketiga, faktor pendekatan belajar dimana faktor yang jenis upaya belajar siswa yang dapat dijelaskan dalam strategi dan metode yang digunakan siswa dalam melakukan kegiatan mempelajari materi pelajaran di dalam proses pembelajaran di sekolah (Syah, 2009).

Dalam kehidupan, manusia dibekali kemampuan berpikir kritis yang berperan penting dalam memecahkan permasalahan hidup. Berpikir merupakan aktivitas yang selalu dilakukan otak untuk metransfer informasi ke seluruh tubuh. Berawal dari proses berpikir tersebut manusia dapat melakukan kegiatan fisik dan non fisik secara normal. Berpikir juga merupakan salah satu hal yang membedakan manusia dengan hewan, sehingga manusia memiliki derajat yang lebih tinggi. Kemampuan berpikir ini sangat diperlukan bagi manusia untuk meneruskan kelangsungan hidupnya, terutama di zaman yang semakin berkembang pesat ini. Berpikir kritis merupakan sebuah kemampuan yang dimiliki setiap orang untuk menganalisis ide atau sebuah gagasan ke arah yang lebih spesifik untuk mengejar pengetahuan yang relevan tentang dunia dengan melibatkan evaluasi bukti. Kemampuan berpikir kritis sangat diperlukan untuk menganalisis suatu permasalahan sampai pada tahap pencarian solusi. Kemampuan berpikir kritis sangat diperlukan untuk menghadapi tantangan global dan berbagai permasalahan kehidupan yang tidak dapat dikendalikan. Kemampuan berpikir 
kritis harus dimiliki oleh siswa. Oleh sebab itu, keterampilan ini harus dikuasai sejak dini termasuk di sekolah dasar. Melalui pendidikan sekolah dasar, siswa diharapkan memperoleh bekal kemampuan berpikir kritis. (Nurdiyanti dan Edy Suryanto, 2010). Berdasarkan hasil studi pendahuluan yang dilakukan dengan guru kelas di Sekolah Dasar Negeri 111 Pekanbaru dapat diketahui bahwasanya siswa tidak termotivasi dalam belajar dan metode ceramah masih dominan dilakukan di kelas sehingga keterampilan berfikir kritis siswa kurang terasah.

Salah satu alternatif yang dapat ditawarkan untuk menanggulangi masalah tersebut adalah dengan menerapkan pembelajaran Discovery Learning. Model pembelajaran Discovery Learning adalah suatu model pembelajaran untuk mengembangkan cara belajar siswa aktif dengan menemukan sendiri, menyelidiki sendiri, maka hasil yang diperoleh akan tahan lama dalam ingatan, tidak akan mudah dilupakan siswa (Wicaksana, dkk 2016). Di dalam model pembelajaran Discovery Learning terdapat stimulation, problem statement, data collection, data processing, verification, dan generalization. Adanya problem statement pada pembelajaran Discovery Learning, guru memberi kesempatan kepada siswa untuk mengidentifikasi sebanyak mungkin masalah yang relevan dengan bahan pelajaran. Untuk memudahkan siswa dalam mengidentifikasi masalah dapat dilakukan dengan kegiatan diskusi kelompok, kemudian siswa diajak untuk mengemukakan hasil pemikirannya didalam kelompok.

Berdasarkan uraian di atas peneliti tertarik mengadakan penelitian dengan judul: Upaya Meningkatkan Kemampuan Berfikir Kritis IPS melalui Model Discovery Siswa di SDN 111 Pekanbaru.

\section{KAJIAN TEORI}

1. Pengertian Kemampuan Berpikir Kritis Pemikiran kritis adalah pemikiran reflektif dan produktif, dan melibatkan evaluasi bukti. (Santrock, 2011). Sedangkan (Jensen, 2011) menyatakan berpikir kritis merupakan proses mental yang efektif dan handal, digunakan dalam mengejar pengetahuan yang relevan dan benar tentang dunia. Selanjutnya kemampuan berpikir kritis yaitu kegiatan menganalisis ide atau gagasan ke arah yang lebih spesifik, membedakannya secara tajam, memilih, mengidentifikasi, mengkaji dan mengembangkannya ke arah yang lebih sempurna (Wijaya, 2010).

Tujuan berpikir kritis menurut (Sapriya, 2011) yaitu untuk menguji suatu pendapat atau ide, termasuk di dalamnya melakukan pertimbangan atau pemikiran yang didasarkan pada pendapat yang diajukan. Pertimbangan-pertimbangan tersebut biasanya didukung oleh kriteria yang dapat dipertanggungjawabkan. Dalam mengembangkan kemampuan berpikir kritis (Jensen, 2011) berpendapat bahwa pemikiran intelejen tidak hanya dapat diajarkan, melainkan juga merupakan bagian fundamental dari paket keterampilan esensial yang diperlukan bagi kesuksesan dalam dunia. Fokus primer pada kreativitas, keterampilan hidup, dan pemecahan masalah membuat pengajaran tentang pemikiran menjadi sangat berarti dan produktif bagi siswa. Berikut ini beberapa keterampilan yang harus ditekankan pada level pengembangan abstraksi dalam mengajarkan pemecahan masalah dan berpikir kritis menurut (Jensen, 2011):

1. Mengumpulkan informasi dan memanfaatkan sumber daya.

2. Mengembangkan fleksibilitas dalam bentuk dan gaya.

3. Meramalkan.

4. Mengajukan pertanyaan bermutu tinggi.

5. Mempertimbangkan bukti sebelum menarik kesimpulan.

6. Menggunakan metafor dan model.

7. Menganalisis dan meramalkan informasi. 


\section{Model Pembelajaran Discovery}

Model pembelajaran Discovery Learning adalah adalah proses mengajar yang mengatur pengajaran sedemikian rupa sehingga anak memperoleh pengetahuan yang sebelumnya belum diketahuinya tidak melalui pemberitahuan, namun ditemukan sendiri. Dalam pembelajaran Discovery, kegiatan atau pembelajaran yang dirancang sedemikian rupa, sehingga siswa dapat menemukan konsep-konsep dan prinsip-prinsip melalui proses mentalnya sendiri (Agus, 2013).

Menurut (Alfieri et al., 2011) pembelajaran Discovery terjadi ketika pelajar tidak disediakan dengan informasi target atau pemahaman konseptual dan harus merasa mandiri dan dengan materi yang disediakan. Discovery learning memberikan kesempatan untuk peserta didik dengan intensif, bimbingan minimal, dan kedua jenis dapat berbagai bentuk simulasi, umpan balik, pemecahan masalah.

Bruner memakai model yang disebutnya Discovery Learning, di mana murid mengorganisasi bahan yang dipelajari dengan suatu bentuk akhir. Model Discovery Learning adalah memahami konsep, arti, dan hubungan, melalui proses intuitif untuk akhirnya sampai kepada suatu kesimpulan (Budiningsih, 2005). Discovery terjadi bila individu terlibat, terutama dalam penggunaan proses mentalnya untuk menemukan beberapa konsep dan prinsip. Discovery dilakukan melalui observasi, klasifikasi, pengukuran, prediksi, penentuan dan inferi.

Mengaplikasikan model Discovery Learning secara berulang-ulang dapat meningkatkan kemampuan penemuan diri individu yang bersangkutan. Penggunaan model Discovery Learning, ingin merubah kondisi belajar yang pasif menjadi aktif dan kreatif. Mengubah pembelajaran yang teacher oriented ke student oriented. Mengubah modus siswa hanya menerima informasi secara keseluruhan dari guru ke modus Discovery siswa menemukan informasi sendiri.

Proses Belajar model Discovery Learning sesungguhnya merupakan pembentukan kategori-kategori atau konsepkonsep, yang dapat memungkinkan terjadinya generalisasi. Sebagaimana teori Bruner tentang kategorisasi yang nampak dalam Discovery, bahwa Discovery adalah pembentukan kategori-kategori, atau lebih sering disebut sistem-sistem coding. Pembentukan kategori-kategori dan sistemsistem coding dirumuskan demikian dalam arti relasi-relasi (similaritas \& difference) yang terjadi diantara obyek-obyek dan kejadiankejadian (events).

Dalam mengaplikasikan metode Discovery Learning guru berperan sebagai pembimbing dengan memberikan kesempatan kepada siswa untuk belajar secara aktif, sebagaimana pendapat guru harus dapat membimbing dan mengarahkan kegiatan belajar siswa sesuai dengan tujuan (Sardiman, 2009). Kondisi seperti ini ingin merubah kegiatan belajar mengajar yang teacher oriented menjadi student oriented. Pada akhirnya yang menjadi tujuan dalam metode Discovery Learning menurut Bruner adalah hendaklah guru memberikan kesempatan kepada muridnya untuk menjadi seorang problem solver, seorang scientist, historian. Melalui kegiatan tersebut siswa akan menguasainya, menerapkan, serta menemukan hal-hal yang bermanfaat bagi dirinya.

\section{METODE PENELITIAN}

Desain penelitian ini adalah PTK (Penelitian Tindakan Kelas). Menurut (Suharsimi, 2006) menyimpulkan bahwa penelitian tindakan kelas adalah suatu upaya untuk mencermati kegiatan belajar sekelompok peserta didik dengan memberikan sebuah tindakan yang sengaja dimunculkan. Penelitian dilaksanakan pada siswa kelas V SD Negeri 111 Pekanbaru, pada semester ganjil 
Tahun Ajaran 2020/2021, dengan jumlah siswa 27 orang. Penelitian tindakan kelas ini dilakukan melalui empat tahap yaitu: perencanaan, pelaksanaan, pengamatan dan refleksi. Penelitian ini terdiri dari 2 siklus yaitu siklus pertama dan siklus kedua. Setiap satu siklus terdiri dari perencanaan tindakan, pelaksanaan tindakan, pengamatan/observasi dan refleksi untuk dilanjutkan ke siklus berikutnya. Sedangkan teknik analisis data dalam penelitian ini adalah analisis statistik deskriptif dengan tujuan untuk mendeskripsikan data-data tentang aktifitas guru dan siswa yang akan diamati.

\section{HASIL DAN PEMBAHASAN}

Kegiatan awal yang dilakukan dalam penelitian ini adalah melakukan wawancara bersama guru mata pelajaran IPS dan observasi terhadap proses pembelajaran IPS di Kelas IV SDN 111 Pekanbaru. Terdapat beberapa pertanyaan yang peneliti ajukan terkait dengan penggunaan strategi pembelajaran yang biasa digunakan guru dalam melaksanakan pembelajaran IPS serta hambatan-hambatan yang dihadapi guru ketika mengajarkan IPS kepada peserta didik.

Selain wawancara, peneliti juga melaksanakan observasi di dalam kelas melihat proses belajar peserta didik pada saat guru mengajarkan pelajaran IPS. Berdasarkan observasi dan wawancara yang dilakukan peneliti, kegiatan belajarnya berlangsung sama seperti sebelumnya. Kesimpulan yang dapat peneliti ambil yaitu bahwasanya guru kurang menerapkan strategi pembelajaran dalam membelajarkan IPS kepada peserta didik. Sehingga perolehan nilai siswa masih banyak yang dibawah nilai KKM (Ketuntasan Kriteria Minimal). Adapun nilai KKM untuk pelajaran IPS kelas V SDN 111 Pekanbaru adalah 70 (tujuh puluh). Data observasi yang peneliti peroleh berdasarkan dari nilai pre-test yang dilakukan oleh guru (peneliti). Dari data tersebut bahwasanya peserta didik di kelas $\mathrm{V}$ masih belum tuntas dalam belajar IPS. Baik dilihat dari kondisi belajarnya, gairah belajar, serta partisipasi dalam belajar IPS.

Observasi juga dilakukan terhadap aktivitas siswa selama kegiatan pembelajaran. Hasil pengamatan awal siswa belum baik dalam mengikuti proses pembelajaran. Perhatian sebagian besar siswa masih tergolong rendah, banyak siswa yang tidak memperhatikan penjelasan guru, ada yang asyik berbicara dengan teman sebangkunya, ada yang sibuk menggambar di buku tulis, bahkan ada yang berjalan-jalan sambil mengganggu teman-temannya.

Dari beberapa data di atas, dapat disimpulkan bahwa pembelajaran IPS siswa kelas V SDN 111 Pekanbaru belum optimal karena kurang keterlibatan siswa dalam proses pembelajaran dan pembelajarannya hanya menggunakan metode ceramah. Penelitian yang dilakukan adalah penerapan model Discovery Learning untuk meningkatkan hasil belajar siswa dan berpikir kritis siswa pada pembelajaran IPS kelas V. Berikut ini tabel pra tindakan (pre test) untuk melihat ketuntasan belajar IPS siswa kelas V. Sedangkan rincian data terlampir.

Tabel 1.Tabel Ketuntasan dan Ketidak tuntasan Pra tindakan

\begin{tabular}{cccc}
\hline No & Jumlah Siswa & Nilai \% & Keterangan \\
\hline 1 & 1 & $3.70 \%$ & Tuntas \\
2 & 36 & $96.30 \%$ & Tidak Tuntas \\
& Nilai rata-rata & & 47.40 \\
\hline
\end{tabular}

Siklus pertama dimulai dengan tahap perencanaan. Hal-hal yang dilakukan pada tahap perencanaan pada siklus I adalah sebagai berikut:

a) Menyiapkan RPP 
b) Menyiapkan lembar evaluasi (Pre Test dan Post Test)

c) Menyiapkan materi ajar

d) Menyiapkan lembar observasi guru

e) Menyiapkan lembar observasi siswa

f) Menyiapkan media dan alat peraga

g) Menyiapkan kartu soal untuk permainan beregu

\section{Deskripsi Hasil Siklus I}

\section{1) Pelaksanaan pembelajaran siklus I}

Kegiatan awal pada pertemuan pertama guru (peneliti) memasuki kelas, kemudian guru (peneliti) mengajak peserta didik untuk berdo"a. Setelah selesai berdoa, guru (peneliti) mengecek kehadiran peserta didik, setelah itu guru (peneliti) memberikan motivasi kepada siswa dengan menginformasikan manfaat materi yang akan dipelajari dalam IPS maupun dalam kehidupan sehari-hari. Kemudian guru (peneliti) menyampaikan tujuan belajar dan hasil belajar yang diharapkan dicapai oleh setiap peserta didik. Kegiatan ini berlangsung selama 10 menit.

Selanjutnya masuk kepada kegiatan inti, yaitu guru menyampaikan materi. Guru (peneliti) membagi peserta didik menjadi beberapa kelompok. Peserta didik duduk berkelompok sesuai kelompoknya masingmasing. Siswa mendengarkan penjelasan dari guru. Pada saat siswa dibagi ke dalam kelompok, siswa tidak bisa tenang, banyak siswa yang protes merasa tidak cocok dengan teman sekelompoknya. Pada saat guru (peneliti) mempersilahkan siswa untuk bergabung dengan teman sekelompoknya, ada siswa yang antusias dan langsung menghampiri teman sekelompoknya, tetapi banyak juga yang kecewa karena tidak sekelompok dengan teman akrabnya.

Setelah terbentuk kelompok, guru (peneliti) membagikan lembar kerja. Kemudian guru (peneliti) menjelaskan persyaratan permainan dalam kelompok agar tidak salah dalam mengerjakannya. Reaksi yang berbeda ditunjukkan oleh siswa, ada sebagian siswa mengerjakan soal yang diberikan guru dan berlomba-lomba dalam permainan tersebut, ada yang tidak peduli dengan tugas yang diberikan. Saat diskusi berlangsung, suasana kelas terlihat kurang kondusif. Ada siswa yang masih mengganggu teman sekelompoknya yang sedang berdiskusi, ada juga siswa yang mengganggu teman kelompok lain yang sedang mengerjakan tugas diskusinya bahkan ada siswa yang bermain. Guru (peneliti) memberikan perhatian lebih dan mengarahkan siswa bekerjasama sebagai satu kelompok. Guru (peneliti) memandu siswa dalam mengkondusifkan suasana di kelas.

Setelah selesai mendiskusikan Guru bersama peserta didik meluruskan kesalah pahaman, memberikan penguatan dan pendalaman atas materi yang telah dipelajari. Selanjutnya, Guru bersama peserta didik membuat kesimpulan atas materi yang dipelajari. Setelah siswa dan guru membuat penguatan pada materi yang diajarkan, lalu guru (peneliti) memberikan evaluasi dan juga soal post test. Adapun keberhasilan yang diperoleh siswa pada post test siklus I ini dapat dilihat dalam tabel berikut:

Tabel 2.Tingkat Keberhasilan Belajar Siswa Berdasarkan Tes Awal (Post Test)

\begin{tabular}{cccc} 
Nilai & Jumlah Siswa & Nilai \% & Keterangan \\
\hline$>70 \%$ & 10 & $37.04 \%$ & Tuntas \\
$<70 \%$ & 17 & $62.96 \%$ & Tidak Tuntas \\
\hline
\end{tabular}


Dari data diatas, bahwasanya tingkat keberhasilan belajar siswa berdasarkan post test pada siklus I dengan persentase ketuntasan sebanyak $37.04 \%$ dengan jumlah 10 siswa dan persentase ketidak tuntasan sebanyak $62.96 \%$ dengan jumlah 17 siswa.

Berdasarkan tabel-tabel yang berisi data nilai hasil belajar siswa di kelas $\mathrm{V}$ tersebut, terlihat bahwa terdapat peningkatan dari rata-rata nilai pada saat pra tindakan adalah $3.70 \%$ menuju nilai $37.04 \%$ pada saat post test di siklus I. Selain dari nilai tersebut jumlah siswa yang memiliki pemahaman dan mengerti tentang materi ajar yang dibawakan guru juga mengalami peningkatan.

Jadi dapat disimpulkan bahwa, dibandingkan pada saat pre test (pra tindakan) terdapat peningkatan yang cukup signifikan walaupun belum mencapai KKM (Kriteria Ketuntasan Minimal) yang diharapkan. Oleh karena itu guru (peneliti) akan melakukan perbaikan untuk lebih meningkatkan hasil belajar peserta didik.

Dengan demikian, tingkat keberhasilan belajar siswa berdasarkan post test pada siklus I dapat digambarkan dalam bentuk grafik sebagai berikut:

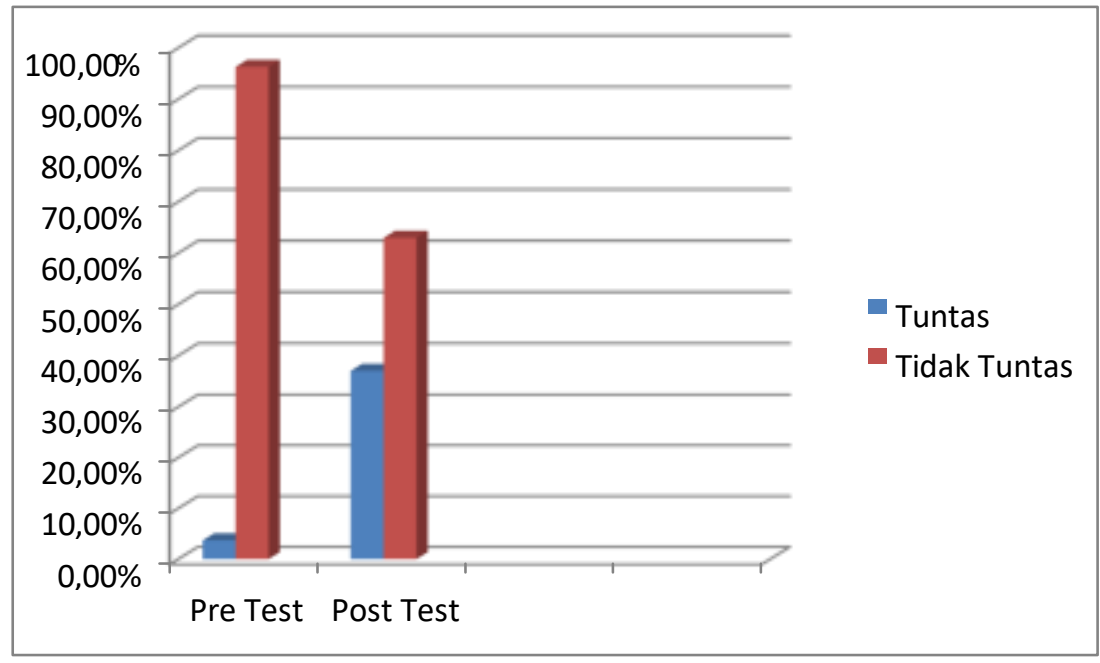

Gambar 1 Peningkatan Hasil Belajar Siswa pada Siklus I

Berdasarkan gambar di atas dengan rumus ketuntasan belajar siswa secara klasikal diperoleh:

$\mathrm{KK}=\frac{\text { jumlah siswa yang tuntas }}{\text { jumlah seluruh siswa }} \times 100$

Maka didapatkanlah hasil sebagai berikut:

$\mathrm{KK}=\frac{10}{27} \times 100=37.04 \%$ (tidak tuntas)

Jika dibandingkan dengan pre test

(pra tindakan) yang dilakukan peneliti, maka pada siklus I dapat dikatakan terjadi peningkatan hasil belajar siswa yang cukup signifikan sebesar $37.04 \%$.

\section{2) Observasi Siklus I}

Pada tahap ini, guru (peneliti) mengadakan pengamatan secara langsung terhadap aktivitas belajar siswa. Guru (peneliti) memperhatikan tingkah laku siswa selama berlangsungnya pembelajaran IPS. Pada tahap ini ada dua jenis lembar observasi yang sudah tersedia, yaitu lembar observasi guru dan lembar observasi siswa. 
ISSN : 2303-1514 | E-ISSN : 2598-5949

Lembar observasi guru akan digunakan oleh guru mata pelajaran IPS untuk menilai proses pembelajaran yang dilaksanakan oleh peneliti yang ketika itu berperan sebagai guru. Sedangkan lembar observasi siswa akan dipegang oleh peneliti yang digunakan untuk menilai aktivitas belajar siswa. Lembar observasi tersebut dapat dilihat dalam tabel berikut:

Tabel 3. Hasil Observasi Guru Mata Pelajaran IPS Terhadap Kemampuan dalam Melaksanakan Pembelajaran

Berilah tanda centang $(\sqrt{ })$ pada kolom $1,2,3$, dan 4 sesuai dengan hasil pengamatan sesuai dengan kriteria sebagai berikut:

Keterangan Skor:

N1 : Kurang Baik

N2 : Cukup

N3 : Baik

N4 : Sangat Baik

\begin{tabular}{|c|c|c|c|c|c|}
\hline \multirow{3}{*}{ No } & \multirow{3}{*}{ Indikator } & \multicolumn{4}{|c|}{ Skor } \\
\hline & & N1 & $\mathbf{N} 2$ & N3 & N4 \\
\hline & & 1 & 2 & 3 & 4 \\
\hline 1. & $\begin{array}{l}\text { Menetapkan bahan pembelajaran sesuai } \\
\text { dengan standar isi }\end{array}$ & & & & $\sqrt{ }$ \\
\hline 2. & $\begin{array}{l}\text { Merumuskan indikator secara tepat dan } \\
\text { benar }\end{array}$ & & & $\sqrt{ }$ & \\
\hline 3. & $\begin{array}{l}\text { Menentukan tujuan pembelajaran } \\
\text { secara tepat dan benar }\end{array}$ & & & & $\sqrt{ }$ \\
\hline 4. & Menguraikan materi secara tepat dan benar & & & $\sqrt{ }$ & \\
\hline 5. & $\begin{array}{l}\text { Menyusun langkah-langkah } \\
\text { pembelajaran secara tepat dan benar }\end{array}$ & & & & $\sqrt{ }$ \\
\hline 6. & $\begin{array}{l}\text { Menentukan strategi dan metode } \\
\text { yang tepat }\end{array}$ & & & & $\sqrt{ }$ \\
\hline 7. & $\begin{array}{l}\text { Menentukan cara-cara memotivasi siswa } \\
\text { agar semangat dalam } \\
\text { mengikuti pembelajaran }\end{array}$ & & & $v$ & \\
\hline 8. & $\begin{array}{l}\text { Menetapkan alokasi waktu secara } \\
\text { tepat }\end{array}$ & & & $\sqrt{ }$ & \\
\hline 9. & $\begin{array}{l}\text { Menentukan media dan sumber } \\
\text { belajar secara tepat }\end{array}$ & & & & $\sqrt{ }$ \\
\hline 10. & $\begin{array}{l}\text { Membuat bentuk penilaian sesuai dengan } \\
\text { indikator }\end{array}$ & & & $\sqrt{ }$ & \\
\hline 11. & $\begin{array}{lll}\text { Menyampaikan } & \text { materi } & \text { dengan } \\
\text { bahasa yang mudah dipahami siswa } & \end{array}$ & & & $\sqrt{ }$ & \\
\hline 12. & $\begin{array}{ll}\text { Menyimpulkan } & \text { pembelajaran } \\
\text { dengan melibatkan siswa } & \end{array}$ & & & & 7 \\
\hline
\end{tabular}


13. $\begin{aligned} & \text { Melaksanakan tindak lanjut dengan } \\ & \text { memberikan arahan, kegiatan, atau tugas }\end{aligned}$

Tabel 6 Hasil Observasi Aktivitas Siswa Pada Saat Kegiatan Pembelajaran Siklus

Berilah tanda $(\sqrt{ })$ pada kolom $1,2,3$, dan 4 sesuai dengan hasil pengamatan sesuai dengan kriteria sebagai berikut:

Skor 1 : Kurang Baik

Skor 2 : Cukup

Skor 3 : Baik

Skor 4 : Sangat Baik

\begin{tabular}{|l|l|c|}
\hline No & \multicolumn{1}{|c|}{ Aspek yang Diamati } & Nilai \\
\hline 1. & Memperhatikan guru ketika menyampaikan materi & 70 \\
\hline 2. & Keaktifan siswa dalam berkelompok & 77 \\
\hline 3. & Kerjasama dalam berkelompok & 75 \\
\hline 4. & Keberanian dalam menjawab soal yang diberikan oleh guru & 80 \\
\hline 5. & Mampu menjawab soal secara tepat dan cepat & 68 \\
\hline \multicolumn{2}{|c|}{ Jumlah skor } & $\mathbf{3 7 0}$ \\
\hline \multicolumn{2}{|c|}{ Rata-Rata } & $\mathbf{1 3 , 7 0}$ \\
\hline
\end{tabular}

Berdasarkan tabel diatas, bisa diketahui bahwasanya aktivitas mengajar yang dilakukan guru kurang optimal. Hal ini di ketahui karena banyak hal yang telah direncanakan belum sesuai dengan realisasinya pada siklus I ini.

\section{3) Refleksi Siklus I}

Setelah dianalisis dapat disimpulkan bahwa pada saat proses pembelajaran siklus I terjadi hambatan antara lain:

a. Ada beberapa siswa yang nilainya rendah, tertinggal dengan temannya, disebabkan karena kurang memahami materi pada saat guru sedang memberikan pelajaran di kelas, seperti beberapa siswa ada yang bergurau sendiri, ada pula siswa yang mengantuk dikelas.

b. Pada saat diskusi terlihat ada siswa yang pasif dan diam, disebabkan karena takut pada temannya yang lebih pandai, mungkin diri siswa tersebut merasa kurang pandai dari pada temannya tersebut.

c. Suasana kelas sedikit ramai bila ada waktu luang, karena siswa lebih banyak suka bergurau dari pada belajar sendiri dikelas walau ada waktu luang yang diberikan oleh guru kelas pada waktu guru sedang meninggalkan kelas.

d. Kemampuan guru mengelola waktu masih kurang, maka perlu adanya

e. perbaikan yang dilanjutkan pada penelitian dalam siklus II.

\section{Deskripsi Hasil Siklus II}

a. Perencanaan Tindakan Siklus II

Pada perencanaan siklus II ini, peneliti kembali menyiapkan perencanaan yang akan diaplikasikan pada siswa kelas V SDN 111 Pekanbaru sebagai solusi untuk mengatasi permasalahan-permasalahan yang telah dipaparkan pada tahap refleksi siklus I 
sebelumnya. Berikut merupakan rincian perencanaannya:

1. Menyiapkan RPP

2. Menyiapkan lembar evaluasi (Post Test)

3. Menyiapkan materi ajar

4. Menyiapkan lembar observasi guru

5. Menyiapkan lembar observasi siswa

6. Menyiapkan media dan alat peraga

7. Menyiapkan kartu soal untuk permainan beregu

8. Menyiapkan reward/hadiah bagi pemenang

\section{b. Pelaksanaan pembelajaran siklus II}

Kegiatan awal pada pertemuan pertama guru (peneliti) memasuki kelas, kemudian guru (peneliti) mengajak peserta didik untuk berdo"a. Setelah selesai berdoa, guru (peneliti) mengecek kehadiran peserta didik, setelah itu guru (peneliti) memberikan motivasi kepada siswa dengan menginformasikan manfaat materi yang akan dipelajari dalam IPS maupun dalam kehidupan sehari-hari. Kemudian guru (peneliti) menyampaikan kembali tujuan pembelajaran pada saat itu, dan bertanya seputar pertanyaan sederhana kepada siswa terkait dengan materi yang mereka anggap sulit. Kegiatan ini berlangsung selama 10 menit.

Sistematika permainan pada siklus II ini berbeda seperti sebelumnya, dimana siswa dibagikan kartu masalah. Lain halnya dengan siklus II ini, guru (peneliti) meminta masingmasing perwakilan kelompok untuk mengutus salah seorang teman kelompok mereka secara bergantian untuk maju ke depan menjawab tantangan soal yang diberikan oleh guru (peneliti). Ketika teman sekelompok mereka maju ke depan menjawab tantangan soal yang diberikan oleh guru, tugas teman-teman yang masih berada di kelompok mereka menunggu giliran menjawab soal yaitu mencatat tantangan soal yang dibacakan guru (peneliti). Setelah mencatat soal yang diberikan guru, maka mereka berdiskusi menjawab soal tersebut. Setelah memecahkan tantangan soal yang mereka catat tersebut, mereka tidak boleh memberitahukan jawaban tersebut kepada teman kelompok mereka yang berada di

depan.

Tabel 3. Tingkat Keberhasilan Belajar Siswa Berdasarkan Hasil (Post Test) Siklus II

\begin{tabular}{cccc}
\hline Nilai & Jumlah Siswa & Nilai $\%$ & Keterangan \\
\hline$>70 \%$ & 25 & $92.59 \%$ & Tuntas \\
$<70 \%$ & 2 & $7.41 \%$ & Tidak Tuntas \\
\hline
\end{tabular}

Dari data tingkat keberhasilan belajar siswa tersebut dapat disimpulkan bahwa pada siklus II mengalami peningkatan yang cukup baik dari pada peningkatan yang sebelumnya. Pada siklus II ini tingkat ketidak tuntasan sudah menurun dari sebelumnya. Berdasarkan perbandingan peningkatan nilai yang dilakukan pada siklus I sebelumnya, maka dapat digambarkan sebagai berikut: 


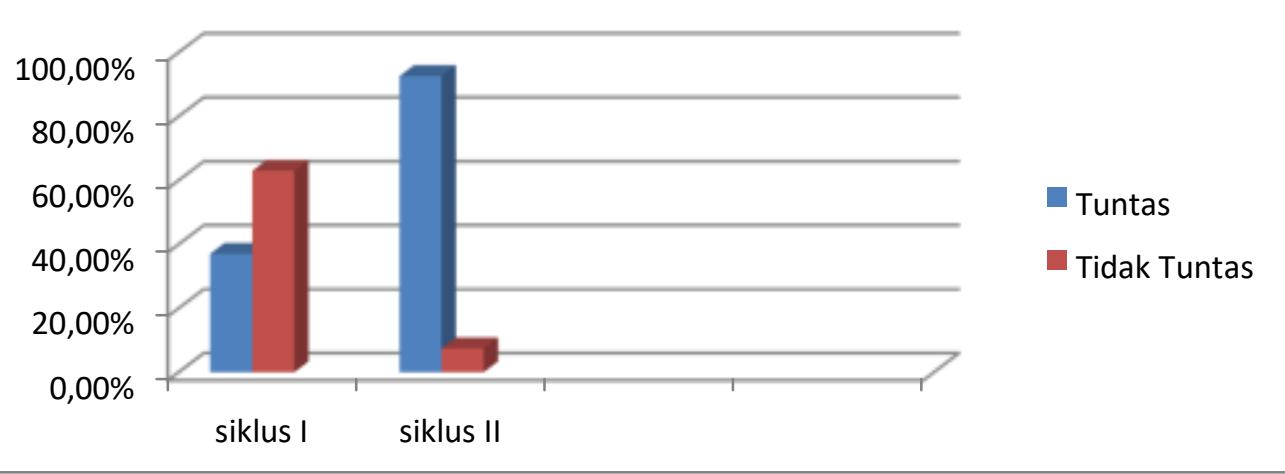

Gambar 2. Peningkatan Hasil Belajar Siswa Pada Siklus I dan Siklus II

\section{c. Observasi Siklus II}

Observasi dilakukan kepada siswa dan peneliti yang berperan sebagai guru. Observasi dilakukan kepada siswa bertujuan untuk mengetahui aktivitas dan respon siswa terhadap proses pembelajaran IPS dengan menggunakan model Discovery Learning. Selain itu, observasi ini juga dilakukan untuk mengetahui sejauh mana keterampilan guru dalam menggunakan model Discovery Learning dalam sebuah pembelajaran serta untuk mengetahui apakah proses pembelajaran telah sesuai dengan apa yang telah direncanakan dalam sebuah RPP yang telah dibuat sebelumnya. Hasil observasi tersebut dapat dilihat dari table dibawah ini:

Tabel 4. Hasil Observasi Guru Mata Pelajaran IPA Terhadap Kemampuan dalam

\section{Melaksanakan Pembelajaran}

Berilah tanda centang $(\sqrt{ })$ pada kolom $1,2,3$, dan 4 sesuai dengan hasil pengamatan sesuai dengan kriteria sebagai berikut:

Keterangan Skor:

N1 : Kurang Baik

N2: Cukup

N3 : Baik

N4 : Sangat Baik

\begin{tabular}{|c|c|c|c|c|c|}
\hline \multirow{3}{*}{ No } & \multirow{3}{*}{ Indikator } & \multicolumn{4}{|c|}{ Skor } \\
\hline & & N1 & $\mathbf{N 2}$ & $\mathbf{N 3}$ & N4 \\
\hline & & 1 & 2 & 3 & 4 \\
\hline 1. & $\begin{array}{l}\text { Menetapkan bahan pembelajaran sesuai dengan } \\
\text { standar isi }\end{array}$ & & & & $\sqrt{ }$ \\
\hline 2. & Merumuskan indikator secara tepat dan benar & & & & $\sqrt{ }$ \\
\hline 3. & $\begin{array}{l}\text { Menentukan tujuan pembelajaran secara tepat dan } \\
\text { benar }\end{array}$ & & & & $\sqrt{ }$ \\
\hline 4. & Menguraikan materi secara tepat dan benar & & & & $\sqrt{ }$ \\
\hline 5. & Menyusun langkah-langkah pembelajaran secara & & & & $\sqrt{ }$ \\
\hline
\end{tabular}


tepat dan benar

6. Menentukan strategi dan metode yang tepat

7. Menentukan cara-cara memotivasi siswa agar semangat dalam mengikuti pembelajaran

8. Menetapkan alokasi waktu secara tepat

9. Menentukan media dan sumber belajar secara tepat

10. Membuat bentuk penilaian sesuai dengan indikator

11. Menyampaikan materi dengan bahasa yang mudah dipahami siswa

12. Menyimpulkan pembelajaran dengan melibatkan siswa

13. Melaksanakan tindak lanjut dengan memberikan arahan, kegiatan, atau tugas

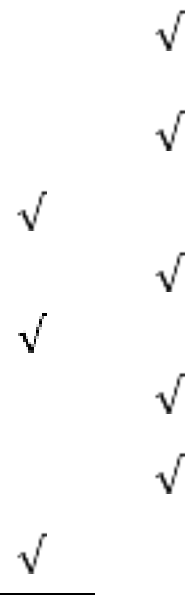

Tabel 5. Hasil Observasi Aktivitas Siswa Pada Saat Kegiatan Pembelajaran Siklus II

Berilah tanda $(\sqrt{)}$ pada kolom 1, 2, 3, dan 4 sesuai dengan hasil pengamatan sesuai dengan kriteria sebagai berikut:

Skor 1 : Kurang Baik

Skor 2 : Cukup

Skor 3 : Baik

Skor 4 : Sangat Baik

\begin{tabular}{llc}
\hline No & \multicolumn{1}{c}{ Aspek yang Diamati } & Nilai \\
\hline 1. & Memperhatikan guru ketika menyampaikan materi & 83 \\
2. & Keaktifan siswa dalam berkelompok & 80 \\
3. $\quad$ Kerjasama dalam berkelompok & 77 \\
4. $\quad$ Keberanian dalam menjawab soal yang diberikan oleh guru & 85 \\
5. Mampu menjawab soal secara tepat dan cepat & 74 \\
Jumlah skor & $\mathbf{3 9 9}$ \\
Rata-Rata & $\mathbf{1 4 . 7 7}$ \\
\hline
\end{tabular}

\section{d. Refleksi Siklus II}

Pelaksanaan siklus II ini terlihat tampak lebih baik dari pada siklus yang ke I. Dalam pelaksanaan pembelajaran kegiatan guru mencapai $92.59 \%$ ketuntasan. Dalam kegiatan pembelajaran siswa juga sudah mengalami perubahan. Kesiapan siswa menerima pelajaran sudah tampak ada perubahan, namun belum maksimal. Masih ada juga hambatan-hambatan yang harus diperbaiki. Keaktifan siswa masih $80 \%$, kemampuan siswa menjawab pertanyaan masih $74 \%$, dan kemampuan siswa mengerjakan soal tes masih $85 \%$ dan yang lainnya.

\section{Pembahasan Hasil Penelitian}

Secara umum keterlibatan siswa dalam proses pembelajaran IPS menggunakan model Discovery Learning maka hasil belajar yang mengalami peningkatan seperti terlihat pada tabel di bawah ini: 
Dari tabel diatas dapat dilihat bahwa siswa yang tuntas belajar sebelum siklus sebanyak 1 siswa (3.70\%), yang tuntas di siklus I sebanyak 10 siswa $(37.04 \%)$ sedangkan disiklus II sebanyak 25 siswa $(92.59 \%)$.

Dengan demikian, dari penjelasan diatas dapat diambil kesimpulan bahwasanya membelajarkan IPS dengan menggunakan model Discovery Learning di SDN 111 Pekanbaru mengalami peningkatan hasil belajar siswa. Lebih jelasnya peningkatan hasil belajar siswa dapat dilihat dari nilai ratarata saat tes awal, hasil belajar siklus I dan siklus II. Seperti tergambar pada diagram dibawah ini:

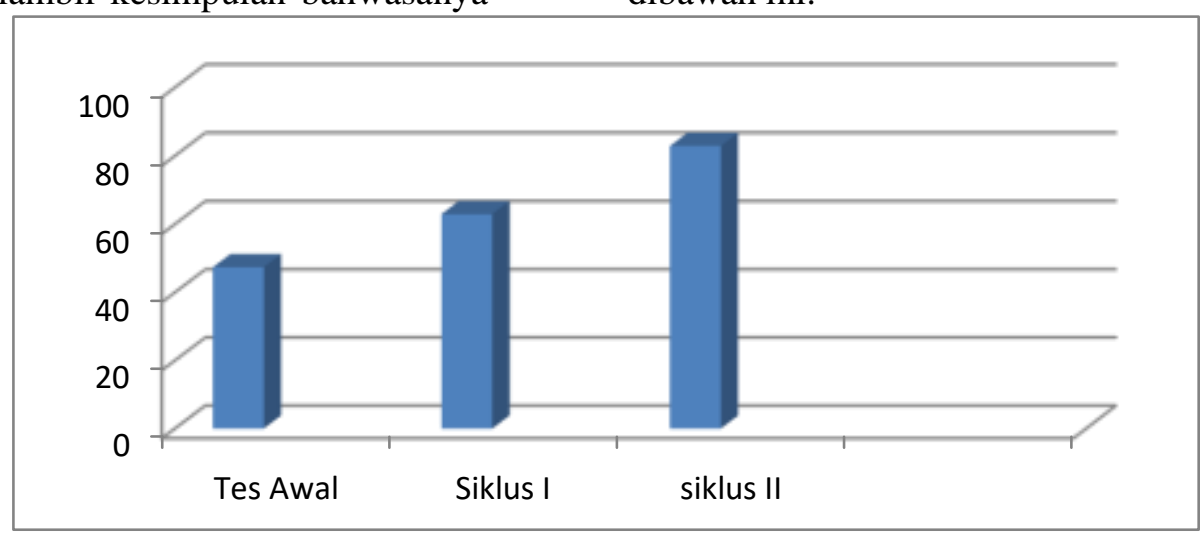

\section{Gambar 3 Peningkatan Hasil Belajar Siswa Mulai Dari Pre Test, Siklus I dan Siklus II}

Pada saat pre test hasil belajar siswa memperoleh nilai rata-rata 47.04 , pada siklus I memperoleh nilai rata-rata 62.96 , dan pada siklus II memperoleh nilai ratarata 82.22. Maka dapat disimpulkan bahwa hasil belajar siswa mulai dari pre test, siklus I, siklus II mengalami peningkatan yang cukup memuaskan. Hal ini dapat membuktikan bahwasanya model Discovery Learning dapat meningkatkan berpikir kritis siswa dilihat dari hasil belajar.

\section{SIMPULAN DAN REKOMENDASI}

Berdasarkan hasil dan pembahasan penelitian dapat diperoleh simpulan bahwa dengan menggunakan model Discovery Learning dapat meningkatkan berpikir kritis siswa dilihat dari hasil belajar siswa pada mata pelajaran IPS di kelas V SDN 111 Pekanbaru, maka hal ini peneliti dapat membuat kesimpulan sebagai berikut: 1) Dari hasil penelitian yang telah dijelaskan bahwasanya proses pembelajaran IPS sebelum dilaksanakannya model Discovery Learning di kelas V SDN 111 Pekanbaru yaitu memiliki tingkat persentase yang rendah. Nilai yang diperoleh hanya $3.70 \%$ yang mendapatkan nilai tuntas dengan jumlah siswa 1 siswa dari 27 siswa; 2) Sementara itu, berdasarkan hasil penelitian yang selanjutnya, proses pembelajaran IPS sesudah diterapkannya model Discovery Learning di Kelas V SDN 111 Pekanbaru ini mengalami peningkatan yang cukup signifikan. Pada siklus I, hasil belajar mengalami peningkatan dengan angka persentase sebanyak $37.04 \%$ dengan jumlah siswa yang tuntas 10 siswa. Sedangkan pada siklus II, hasil belajar $92.59 \%$ dengan jumlah siswa yang tuntas sebanyak 25 siswa dari 27 siswa di kelas V SDN 111 Pekanbaru. Dari data tersebut, hasil yang didapatkan adalah bahwasanya penelitian yang dilakukan menggunakan strategi Discovery Learning ini berhasil dilakukan dengan nilai yang memuaskan dan melewati nilai KKM yaitu 70 . Dan 3) respon dan kesan siswa terhadap model 
ISSN : 2303-1514 | E-ISSN : 2598-5949

DOI : http://dx.doi.org/10.33578/jpfkip.v10i6.8616

https://primary.ejournal.unri.ac.id/index.php/JPFKIP

Discovery Learning dalam hasil belajar pada mata pelajaran IPS mencapai kategori baik sekali sesuai dengan data persentase observasi siswa yang telah dibahas sebelumnya. Selain itu, siswa merasa senang belajar IPS sambil bermain, strategi ini juga mendidik siswa untuk lebih kompetitif di dalam kelas. Dengan penerapan strategi ini juga banyak memberikan pengalaman menarik bagi siswa.

\section{DAFTAR PUSTAKA}

Agus, N. (2013). Panduan Aplikasi TeoriTeori Belajar Mengajar, Yogyakarta: Diva Press

Arikunto, S. (2006). Prosedur Penelitian Suatu Pendekatan Praktik. Jakarta : PT Rineka Cipta

Alfieri, L., Brooks, P. J., Aldrich, N. J., \& Tenenbaum, H. R. (2011). Does Discovery Based Instruction Enhance Learning. Journal of Educational Psychology, 103(1), 1-18.

Asmadi, A. (2004). Pendekatan Kuantitatif dan Kualitatif dalam Penelitian Pendidikan, Intuisi. Yogyakarta

Budiningsih, A. (2005). Belajar dan Pembelajaran. Jakarta: Rineka Cipta.

Cece, W. (2010). Pendidikan Remidial: Sarana Pengembangan Mutu Sumber Daya Manusia. Bandung: PT Remaja Rosdakarya.
Djamarah, S. (2002). Strategi Belajar Mengajar. Jakarta:PT Rineka Cipta

Hamalik, O. (2010). Proses Belajar Mengajar. Jakarta: PT Bumi Aksara.

Jensen, E. (2011). Pembelajaran BerbasisOtak. Paradigma Pengajaran Baru. Jakarta: PT Indeks

John W. Santrock. (2011). Life Span Development Perkembangan Masa Hidup Edisi 13: Erlangga dengan Power Macpro

Nurdiyanti, E., dan Edy, S. (2010). Pembelajaran Literasi Mata Pelajaran Bahasa Indonesia pada Siswa Kelas V Sekolah Dasar. Jurnal Paedagogia. Volume 13 No 2.

Sapriya. (2011). Pendidikan IPS . Bandung: Remaja Rosdya Karya.

Sardiman. (2009). Interaksi dan Berfikir kritis. PT Raja Grafindo Persada. Jakarta.

Syah, M. (2009). Psikologi Pendidikan Suatu Pendekatan Baru. Bandung: Remaja Rosdakarya.

Wicaksana, H. M., dan Usodo, B., (2016). Eksperimentasi Model Pembelajaran Problem Based Learning (PBL) dan Discovery Learning (DL) dengan Pendekatan Saintifik Ditinjau dari Advertisy Quotient (AQ) Siswa. Jurnal Elektronik Pembelajaran Matematika, 4(3):258-269. 